\title{
Effect of dietary iodine on production of iodine enriched eggs
}

\author{
Shaikh Sumaiya ${ }^{1}$, Sunil Nayak ${ }^{1}$, R. P. S. Baghel ${ }^{1}$, Anju Nayak ${ }^{2}$, C. D. Malapure ${ }^{1}$ and Rajesh Kumar $^{1}$ \\ 1. Department of Animal Nutrition, College of Veterinary Science and Animal Husbandry, Jabalpur - 482001 , \\ Madhya Pradesh, India; 2. Department of Veterinary Microbiology, College of Veterinary Science and Animal Husbandry, \\ Jabalpur - 482 001, Madhya Pradesh, India. \\ Corresponding author: Sunil Nayak, e-mail: sunilnayak91@yahoo.com, \\ SS: drsumaiyakoul@gmail.com, RPSB: rameshbaghel@yahoo.co.in, AN: nayakanju@rediffmail.com, \\ CDM: cdmalapure@gmail.com, RK: rajeshkumarmahla46@gmail.com \\ Received: 05-02-2016, Accepted: 27-04-2016, Published online: 04-06-2016
}

doi: 10.14202/vetworld.2016.554-558 How to cite this article: Sumaiya S, Nayak S, Baghel RPS, Nayak A, Malapure CD, Kumar R (2016) Effect of dietary iodine on production of iodine enriched eggs, Veterinary World, 9(6): 554-558.

\begin{abstract}
Aim: Objective of this study was to investigate the effect of different levels of iodine supplementation on iodine content of eggs in laying hens.

Materials and Methods: In the experiment, 135 laying hens (White Leghorn) of 55 weeks age were randomly distributed to 5 dietary treatments; each group contained 27 laying hens distributed in three replicates of 9 birds each. Diet $T_{1}$ was control basal layer diet without iodine enrichment in which iodine content $\left(\mathrm{I}_{2}\right)$ was as per NRC recommendation. Basal diets were supplemented with calcium iodate $\left(\mathrm{Ca}\left(\mathrm{IO}_{3}\right)_{2}\right)$ at $5,10,15$ and $20 \mathrm{mg} / \mathrm{kg}$ in $\mathrm{T}_{2}, \mathrm{~T}_{3}, \mathrm{~T}_{4}$ and $\mathrm{T}_{5}$ groups, respectively. The iodine content in the calcium iodate is $65.21 \%$, therefore, the diets $\mathrm{T}_{2}, \mathrm{~T}_{3}, \mathrm{~T}_{4}$ and $\mathrm{T}_{5}$ contained $3.25,6.50,9.75$ and $13.0 \mathrm{ppm}$ iodine, respectively. The laying hens were fed the respective experimental diets ad libitum during the experimental period of 10 -week. The iodine content of egg yolk and albumen was analyzed at the end of $5^{\text {th }}$ and $10^{\text {th }}$ week of the experiment. Economics of feeding for the production of iodine enriched egg was calculated at the end of the experiment.
\end{abstract}

Results: Increasing iodine levels in diet of hens from 0.45 to $13.0 \mathrm{ppm}$ significantly increased egg iodine concentration, the highest concentration of egg iodine was observed in the group fed diet supplemented with 13.0 ppm iodine followed by those fed $9.75,6.50,3.25$ and 0.45 ppm iodine in diet. There was no significant difference in the iodine levels of unboiled versus boiled eggs. Therefore, the consumers are ensured to receive the optimal levels of iodine from boiled iodine-enriched eggs. Among different diets, minimum and significantly lower feeding cost (Rs. per dozen or per kg eggs) was noticed in hens allotted $\mathrm{T}_{3} \operatorname{diet}\left(6.50 \mathrm{ppm} \mathrm{I}_{2}\right)$. However, feeding cost of hens receiving 3.25 and $9.25 \mathrm{ppm} \mathrm{I}_{2}$ was statistically ( $\left.\mathrm{p}<0.05\right)$ similar to control group $\left(\mathrm{T}_{1}\right)$. Further, it was noticed that feeding cost (Rs. per dozen or per kg eggs) was significantly increased due to the inclusion of higher level of iodine $(13.0 \mathrm{ppm})$.

Conclusion: It was concluded that supplementing iodine at $6.50 \mathrm{ppm}$ in layers diet was economically better for the production of iodine enriched eggs followed by feed iodine supplementation at $3.25 \mathrm{ppm}$ as compared to control and other treatment groups.

Keywords: eggs, iodine, layers, performance.

\section{Introduction}

Egg is considered as a complete food with the most of the nutrients required for well-being. In addition to the nutrients already available in the egg if we can alter or incorporate certain health beneficiary nutrients then these eggs will be the choice of food for health conscious people and can reduce the chances of occurrence of certain diseases. Enriched egg with trace minerals results in eggs with superior biological and nutritional value for human consumption [1]. Surveys carried out by Indian Council of Medical Research have shown that no state or union territory is free from the problem of iodine deficiency disorders (IDDs). Out of 586 districts in the country,

Copyright: Sumaiya, et al. Open Access. This article is distributed under the terms of the Creative Commons Attribution 4.0 International License (http://creativecommons.org/licenses/ by/4.0/), which permits unrestricted use, distribution, and reproduction in any medium, provided you give appropriate credit to the original author(s) and the source, provide a link to the Creative Commons license, and indicate if changes were made. The Creative Commons Public Domain Dedication waiver (http:// creativecommons.org/publicdomain/zero/1.0/) applies to the data made available in this article, unless otherwise stated.
281 districts have been surveyed for IDD and 41 districts have been found to be endemic [2], therefore, an improvement of iodine supply is still a great challenge for nutritionists.

Iodine $\left(I_{2}\right)$ is an essential micronutrient for humans and animals and its deficiency reduces the production of thyroid hormones, leads to the morphological and functional changes of the thyroid gland [3]. Fortification of various nutrients in egg is solely dependent on nutritional manipulation of the laying hen's ration [4]; therefore, iodine enrichment can be achieved by dietary manipulation of hen's diet. McDowell [5] pointed to a preferential interception of iodine in the hen ovary and an easy passage of iodine to oocytes. Experimental knowledge of factors participating in the relatively easy iodine passage to yolk makes it possible to increase iodine content in eggs.

The significance of this study is that the iodine supplementation in layer diets could increase the levels of iodine in hen eggs and can lead to prevention of iodine deficiency in humans. 
The aim of this study was to investigate the effect of supplementation of iodine at different levels in layers diet on egg iodine content and economics of feeding.

\section{Materials and Methods}

\section{Ethical approval}

The experiment on animals including all procedures of this study was approved by Institutional Animal Ethics Committee.

\section{Stock, diet and husbandry}

In the experiment, 135 laying hens (White Leghorn) of 55 weeks age were randomly distributed to 5 dietary treatments; each group contained 27 laying hens distributed in three replicates of 9 birds each. $\mathrm{T}_{1}$ was basal layer diet without iodine enrichment (control), in which iodine $\left(\mathrm{I}_{2}\right)$ content was as per NRC [6] recommendation (0.45 ppm). Basal diets were supplemented with calcium iodate $\left(\mathrm{Ca}\left(\mathrm{IO}_{3}\right)_{2}\right)$ at $5,10,15$ and $20 \mathrm{mg} / \mathrm{kg}$ in $\mathrm{T}_{2}, \mathrm{~T}_{3}, \mathrm{~T}_{4}$ and $T_{5}$ groups, respectively. Therefore, dietary iodine $\left(\mathrm{I}_{2}\right)$ content in diets $\mathrm{T}_{2}, \mathrm{~T}_{3}, \mathrm{~T}_{4}$ and $\mathrm{T}_{5}$ was $3.25,6.50$, 9.75 and $13.00 \mathrm{ppm}$, respectively. All the diets were formulated as per NRC [6] recommendation using feed ingredients such as maize, soybean meal, and de-oiled rice polish. Ingredients and nutrient composition of all the diets are presented in Table-1. The experiment was for 10 weeks.

All the laying hens were shifted to experimental layer house. The system of rearing was cage system. The house was cleaned, white washed, fumigated, and sprayed with disinfectant before introducing the birds in it and was provided with a sufficient light source. Layer mash was offered ad-libitum to the hens in feeders. Care was taken that feeders are full of feed at all time and constant watch was kept to avoid feed wastage. An ample supply of clean and fresh drinking water was made available to the laying hens all the time through simple water channel type waterer. During the experiment, the eggs were collected thrice daily, i.e., at $9.00 \mathrm{am} ; 12.00$ noon and at $3.00 \mathrm{pm}$ replicate wise and where weighed at $4.00 \mathrm{pm}$ daily.

\section{Parameters studied}

Total 60 eggs ( 12 eggs from each treatment) were collected randomly at the end of $5^{\text {th }}$ and $10^{\text {th }}$ week of the experiment for iodine estimation. The iodine concentration in the egg yolk and albumin was determined by a spectrophotometer method $(440 \mathrm{~nm})$ using alkaline ashing based on the Sandell-Kolthoff reaction [7]. The principle of the assessment was the reduction of $\mathrm{Ce}^{4+}$ to $\mathrm{Ce}^{3+}$ in the presence of $\mathrm{As}^{3+}$ and the catalytic effect of iodine. Mineralization took place in an alkaline medium at $600^{\circ} \mathrm{C}$. In this method, organic sample fades away as the result of a high temperature and iodine released from the organic compound attaches to alcoholic group. The resulting product was not soluble in acid and thus the iodine content was determined chromatographically. In this method, iodine catalyzes a reductive oxidation reaction. In the same manner
Table-1: Ingredients and nutrient composition of layer diets $(\%)$.

\begin{tabular}{|c|c|c|c|c|c|}
\hline \multirow[t]{2}{*}{ Ingredients } & \multicolumn{5}{|c|}{ Diets } \\
\hline & $T_{1}$ & $\mathbf{T}_{2}$ & $\mathbf{T}_{3}$ & $\mathbf{T}_{4}$ & $\mathbf{T}_{5}$ \\
\hline Maize $(\mathrm{kg})$ & 53.00 & 53.00 & 53.00 & 53.00 & 53.00 \\
\hline DORP $(\mathrm{kg})$ & 16.80 & 16.80 & 16.80 & 16.80 & 16.80 \\
\hline SBM $(\mathrm{kg})$ & 19.00 & 19.00 & 19.00 & 19.00 & 19.00 \\
\hline DCP (kg) & 0.400 & 0.400 & 0.400 & 0.400 & 0.400 \\
\hline LSP (kg) & 03.00 & 03.00 & 03.00 & 03.00 & 03.00 \\
\hline Shell grit (kg) & 07.00 & 07.00 & 07.00 & 07.00 & 07.00 \\
\hline Salt (kg) & 0.360 & 0.360 & 0.360 & 0.360 & 0.360 \\
\hline $\mathrm{MnSO}_{4}(\mathrm{~kg})$ & 0.054 & 0.054 & 0.054 & 0.054 & 0.054 \\
\hline $\mathrm{ZnSO}_{4}(\mathrm{~kg})$ & 0.10 & 0.10 & 0.10 & 0.10 & 0.10 \\
\hline $\mathrm{CuSO}_{4}(\mathrm{~kg})$ & 0.01 & 0.01 & 0.01 & 0.01 & 0.01 \\
\hline $\mathrm{FeSO}_{4}(\mathrm{~kg})$ & 0.139 & 0.139 & 0.139 & 0.139 & 0.139 \\
\hline $\mathrm{Ca}\left(\mathrm{IO}_{3}\right)_{2}(\mathrm{~kg})$ & 0.004 & 0.032 & 0.065 & 0.097 & 0.13 \\
\hline $\begin{array}{l}\text { Vitamin } A, B_{2}, D_{3} \\
K(k g)^{*}\end{array}$ & 0.025 & 0.025 & 0.025 & 0.025 & 0.025 \\
\hline $\begin{array}{l}\text { Vitamin B complex } \\
(\mathrm{kg})^{*}\end{array}$ & 0.005 & 0.005 & 0.005 & 0.005 & 0.005 \\
\hline Salinomycin (kg) & 0.044 & 0.044 & 0.044 & 0.044 & 0.044 \\
\hline Total (kg) & 100.00 & 100.00 & 100.00 & 100.00 & 100.00 \\
\hline \multicolumn{6}{|l|}{$\begin{array}{l}\text { Nutrient } \\
\text { composition } \\
\text { analyzed }\end{array}$} \\
\hline $\mathrm{CP}(\%)$ & 16.15 & 16.32 & 16.20 & 16.29 & 16.27 \\
\hline $\mathrm{Ca}(\%)$ & 03.47 & 03.56 & 03.38 & 03.65 & 03.73 \\
\hline Iodine $(\mathrm{mg} / \mathrm{kg})$ & 0.45 & 03.25 & 06.50 & 09.75 & 13.00 \\
\hline \multicolumn{6}{|l|}{$\begin{array}{l}\text { Nutrient } \\
\text { composition } \\
\text { calculated }\end{array}$} \\
\hline ME (kcal/kg) & 2602 & 2602 & 2602 & 2602 & 2602 \\
\hline Lysine (\%) & 0.66 & 0.66 & 0.66 & 0.66 & 0.66 \\
\hline Methionine (\%) & 0.26 & 0.26 & 0.26 & 0.26 & 0.26 \\
\hline
\end{tabular}

*Vitamin premix provided (each $250 \mathrm{~g}$ contains):

Vitamin A - 10,000,000 IU; Vitamin $D_{3}-2,000,000$ IU; Vitamin $B_{1}-800 \mathrm{mg}$; Vitamin $B_{2}-5 \mathrm{~g}$; Vitamin $B_{6}-1.6$ g; Vitamin $B_{12}-20.5 \mathrm{~g}$; Niacin - $12.0 \mathrm{~g}$; Calcium D panthothenate $-8.0 \mathrm{~g}$; Vitamin $\mathrm{K}_{3}-1.0 \mathrm{~g}$; Vitamin E - $8.0 \mathrm{~g}$; Folic acid $-800 \mathrm{mg}$, DCP=Digestible crude protein, LSP=Left sacrum posterior, SBM=Soybean meal, $\mathrm{DORP}=$ De-oiled rice polish

the iodine content was also measured after boiling the eggs.

All the experimental diets were analyzed for proximate compositions as per AOAC [8]. The economics of feeding was calculated as the cost of feed consumed in rupees for production of one dozen eggs as well as for one $\mathrm{kg}$ egg mass.

\section{Statistical analysis}

The data obtained during the experiment were analyzed statistically using the methods described by Snedecor and Cochran [9]. Differences between the treatments were tested for significance by Duncan's new multiple range test using statistical software SPSS.

\section{Results}

Effects of dietary iodine on iodine composition of egg

The concentration of iodine in egg yolk and albumen (before and after boiling) of laying hens fed on various levels of iodine after $5^{\text {th }}$ week of supplementation is presented in Table- 2 . The treatment means of the iodine concentration in eggs (before 
boiling) of laying hens fed on various levels of iodine after $5^{\text {th }}$ week of supplementation indicated that the inclusion of different levels of iodine significantly $(p<0.05)$ increased iodine content of egg yolk as well as albumen. Maximum and significantly $(\mathrm{p}<0.05)$ higher iodine content in egg yolk $(1.17 \pm 0.025 \mu \mathrm{g} / \mathrm{g})$ and egg albumin $(0.12 \pm 0.001 \mu \mathrm{g} / \mathrm{g})$ were recorded in layers assigned $\mathrm{T}_{5}\left(13 \mathrm{ppm} \mathrm{I}_{2}\right)$ diet. Iodine content in egg yolk and albumen linearly decreased in layers assigned $\mathrm{T}_{4}(9.7 \mathrm{ppm} \mathrm{I}), \mathrm{T}_{3}\left(6.50 \mathrm{ppm} \mathrm{I}_{2}\right)$, and $\mathrm{T}_{2}$ (3.25 ppm $\mathrm{I}_{2}$ ) diets, respectively. Minimum and significantly $(\mathrm{p}<0.05)$ lowest concentration of iodine content in egg yolk $(0.19 \pm 0.005 \mu \mathrm{g} / \mathrm{g})$ and egg albu$\min (0.02 \pm 0.002 \mu \mathrm{g} / \mathrm{g})$ was found in layers assigned $\mathrm{T}_{1}$ (control) diet. The treatment means of the iodine concentration in eggs (after boiling) indicated that the use of higher levels of iodine significantly $(p<0.05)$ increased iodine content of egg yolk as well as albumen. Maximum and significantly $(\mathrm{p}<0.05)$ higher iodine content of egg (after boiling) was noted in layers assigned $T_{5}\left(13 \mathrm{ppm} \mathrm{I}_{2}\right)$ diet. Iodine content in boiled egg yolk and albumen linearly decreased in layers assigned $\mathrm{T}_{4}\left(9.75 \mathrm{ppm} \mathrm{I}_{2}\right), \mathrm{T}_{3}\left(6.50 \mathrm{ppm} \mathrm{I}_{2}\right)$ and $\mathrm{T}_{2}\left(3.25 \mathrm{ppm} \mathrm{I}_{2}\right)$ diets, respectively. It was observed that about $10-15 \%$ iodine was lost after boiling the eggs.

Iodine concentration in egg yolk and albumen (before and after boiling) of laying hens fed various levels of iodine after $10^{\text {th }}$ week of supplementation (before and after boiling) is presented in the Table-3. The trend for iodine content in egg yolk and albumen was similar in the case of both boiled and unboiled eggs. The iodine content of eggs was significantly influenced due to the inclusion of different levels of iodine above recommended levels in the diet of laying hens. Among iodine supplemented groups, maximum and significantly $(\mathrm{p}<0.05)$ higher iodine content of egg yolk and albumen was recorded in hens assigned $\mathrm{T}_{5}\left(13 \mathrm{ppm} \mathrm{I}_{2}\right)$ diet. Iodine content in egg yolk and albumen linearly decreased in layers assigned $\mathrm{T}_{4}, \mathrm{~T}_{3}$ and $T_{2}\left(9.75,6.50\right.$ and 3.25 ppm $\left.\mathrm{I}_{2}\right)$ diets, respectively. Significantly $(\mathrm{p}<0.05)$ lowest iodine concentration in egg yolk and albumin was found in layers assigned $\mathrm{T}_{1}$ (control) diet. The treatment means of the iodine concentration indicated that, use of higher levels of iodine significantly $(p<0.05)$ increased iodine content of egg yolk as well as albumen. Further, it was observed that about $10-15 \%$ iodine is lost on boiling the eggs.

\section{Effect of iodine supplementation on economics of feeding}

The economics of feeding for the production of iodine enriched eggs is presented in Table- 4 . The results of this study revealed that among iodine supplemented diets, significantly $(\mathrm{p}<0.05)$ lowest feeding cost (Rs. per dozen or per kg egg mass) was noticed in layers receiving $6.50 \mathrm{ppm}$ iodine in their diet. However, feeding cost (Rs. per dozen or per kg egg mass) of layers receiving 3.25 and $9.75 \mathrm{ppm}$ iodine in their diet was statistically similar $(\mathrm{p}>0.05)$ and comparable to control $\left(0.45 \mathrm{ppm} \mathrm{I}_{2}\right)$. Further, inclusion of higher levels of iodine significantly $(p<0.05)$ increased the feeding cost (Rs. per dozen or per $\mathrm{kg}$ eggs) in layers. Feed cost (Rs. per kg) was near about similar in all treatments since the price of iodine source was very low.

\section{Discussion}

Iodine content in eggs yolk and albumen, both after $5^{\text {th }}$ week and $10^{\text {th }}$ week of supplementation, linearly increased with the increasing iodine levels $(0.45$, $3.25,6.50$ and $13.0 \mathrm{ppm} \mathrm{I}_{2}$ ) in their diets. This increment may be due to the higher iodine transfer from

Table-2: Concentration of iodine in eggs of laying hens fed on various levels of iodine after $5^{\text {th }}$ week of supplementation (before and after boiling).

\begin{tabular}{|c|c|c|c|c|c|}
\hline \multirow[t]{2}{*}{ Treatments } & \multirow{2}{*}{$\begin{array}{c}\text { Iodine level } \\
(\mathrm{ppm})\end{array}$} & \multicolumn{2}{|c|}{ Yolk iodine $(\mu \mathrm{g} / \mathrm{g})$} & \multicolumn{2}{|c|}{ Albumen iodine $(\mu \mathrm{g} / \mathrm{g})$} \\
\hline & & Before boiling & After boiling & Before boiling & After boiling \\
\hline$\overline{T_{1}}$ & 0.45 & $0.19^{\mathrm{e}} \pm 0.005$ & $0.17^{d} \pm 0.014$ & $0.02^{d} \pm 0.002$ & $0.02^{c} \pm 0.002$ \\
\hline $\mathrm{T}_{2}^{1}$ & 03.25 & $0.27^{\mathrm{d}} \pm 0.005$ & $0.20^{\mathrm{d}} \pm 0.014$ & $0.04^{c} \pm 0.001$ & $0.03^{c} \pm 0.001$ \\
\hline $\mathrm{T}_{3}^{2}$ & 06.50 & $0.52^{c} \pm 0.029$ & $0.44^{c} \pm 0.015$ & $0.07^{b} \pm 0.002$ & $0.06^{b} \pm 0.002$ \\
\hline $\mathrm{T}_{4}^{3}$ & 09.75 & $0.81^{b} \pm 0.008$ & $0.71^{b} \pm 0.018$ & $0.08^{b} \pm 0.003$ & $0.07^{b} \pm 0.001$ \\
\hline $\mathrm{T}_{5}^{4}$ & 13.00 & $1.17^{\mathrm{a}} \pm 0.025$ & $1.03^{a} \pm 0.012$ & $0.12^{\mathrm{a}} \pm 0.001$ & $0.11^{\mathrm{a}} \pm 0.002$ \\
\hline
\end{tabular}

Mean values bearing different superscript differ significantly $(p<0.05)$

Table-3: Concentration of iodine in eggs of laying hens fed on various levels of iodine after $10^{\text {th }}$ week of supplementation (before and after boiling).

\begin{tabular}{|c|c|c|c|c|c|}
\hline \multirow[t]{2}{*}{ Treatments } & \multirow{2}{*}{$\begin{array}{l}\text { Iodine level } \\
\quad(\mathrm{ppm})\end{array}$} & \multicolumn{2}{|c|}{ Yolk iodine $(\mu \mathrm{g} / \mathrm{g})$} & \multicolumn{2}{|c|}{ Albumen iodine $(\mu \mathrm{g} / \mathrm{g})$} \\
\hline & & Before boiling & After boiling & Before boiling & After boiling \\
\hline$T_{1}$ & 0.45 & $0.20^{\mathrm{e}} \pm 0.014$ & $0.18^{\mathrm{e}} \pm 0.017$ & $0.02^{\mathrm{e}} \pm 0.001$ & $0.02^{\mathrm{e}} \pm 0.001$ \\
\hline $\mathrm{T}_{2}^{1}$ & 03.25 & $0.28^{d} \pm 0.014$ & $0.23^{\mathrm{d}} \pm 0.020$ & $0.05^{d} \pm 0.001$ & $0.04^{d} \pm 0.002$ \\
\hline $\mathrm{T}_{3}^{2}$ & 06.50 & $0.60^{c} \pm 0.014$ & $0.51^{c} \pm 0.014$ & $0.07 c \pm 0.001$ & $0.06^{c} \pm 0.002$ \\
\hline $\mathrm{T}_{4}^{3}$ & 09.75 & $0.84^{b} \pm 0.023$ & $0.72^{b} \pm 0.020$ & $0.09^{b} \pm 0.002$ & $0.08^{b} \pm 0.002$ \\
\hline $\mathrm{T}_{5}^{4}$ & 13.00 & $1.20^{\mathrm{a}} \pm 0.021$ & $1.03^{\mathrm{a}} \pm 0.002$ & $0.12^{\mathrm{a}} \pm 0.002$ & $0.11^{\mathrm{a}} \pm 0.002$ \\
\hline
\end{tabular}

Mean values bearing different superscript differ significantly $(p<0.05)$ 
Table-4: Economics of feeding for production of iodine enriched eggs.

\begin{tabular}{lccc}
\hline Treatments & $\begin{array}{c}\text { Iodine } \\
\text { level } \\
\text { (ppm) }\end{array}$ & $\begin{array}{c}\text { Feed cost } \\
\text { kg feed/dozen } \\
\text { eggs (Rs.) }\end{array}$ & $\begin{array}{c}\text { Feed cost } \\
\text { kg feed/ kg } \\
\text { eggs (Rs.) }\end{array}$ \\
\hline $\mathrm{T}_{1}$ & 0.45 & $32.56^{\mathrm{b}} \pm 0.167$ & $46.22^{\mathrm{b}} \pm 0.763$ \\
$\mathrm{~T}_{2}$ & 03.25 & $32.43^{\mathrm{b}} \pm 0.167$ & $46.31^{\mathrm{b}} \pm 0.480$ \\
$\mathrm{~T}_{3}$ & 06.50 & $32.06^{\mathrm{c}} \pm 0.063$ & $45.58^{\mathrm{c}} \pm 0.184$ \\
$\mathrm{~T}_{4}$ & 09.75 & $32.81^{\mathrm{b}} \pm 0.418$ & $46.80^{\mathrm{b}} \pm 0.663$ \\
$\mathrm{~T}_{5}$ & 13.00 & $34.07^{\mathrm{a}} \pm 0.126$ & $50.47^{\mathrm{a}} \pm 0.223$ \\
\hline
\end{tabular}

Mean values bearing different superscript differ significantly $(p<0.05)$

feed to egg. The results of iodine concentration are consistent with the findings of Kaufmann et al. [10], who found a significant linear correlation $(r=0.93)$ between iodine content in feed mixture up to $5 \mathrm{mg} / \mathrm{kg}$ and iodine content in yolk. Yang et al. [11] indicated that laying hens might be a good carrier for transporting iodine, from diet to egg. Ramune et al. [12] found that in eggs from laying hens receiving feed containing 1 and $4 \mathrm{ppm}$ iodine, egg iodine content was $24 \%$ and $196 \%$ more than control group. Moreover, Songserm et al. [13] revealed that $4000 \mathrm{mg}$ supplemental iodine/ton diet in two forms potassium iodide or potassium iodate increased the iodine concentration of eggs. In support to the results of this study introduction of iodine supplement from 1 to $5 \mathrm{mg} / \mathrm{kg}$ into the diet of hens enabled the significant enrichment of the egg iodine content [14]. Saki et al. [15] indicated that increased albumen and yolk iodine is proportional to level of supplementary iodine in diet $(\mathrm{p}<0.05)$. Similarly, Gjorgovska and Kiril [16] stated that when laying hen feed enriched with $5 \mathrm{mg}$ iodine $/ \mathrm{kg}$ diet, the yolk from eggs of such hens is better source of iodine and can fulfill $11-15 \%$ of daily requirements for adult people if they consume one egg per day. Travnicek et al. [17] found that when iodine content in feed mixtures was raised from 0.22 to $1.18 \mathrm{mg} / \mathrm{kg}$ dietary dry matter, iodine content in egg yolk was increased significantly. Malak et al. [18] in their experiment also observed that increasing iodine levels from 0.3 to $9.6 \mathrm{ppm}$ in hens diet significantly increased egg iodine concentration and the highest concentration of egg iodine was observed for the hens fed diet supplemented with $9.6 \mathrm{ppm}$ followed by those fed $4.8 \mathrm{ppm}$ iodine, while these high levels of iodine negatively affected the egg production. They concluded that supplementation of laying hen diet with $2.4 \mathrm{mg}$ iodine/ $\mathrm{kg}$ diet gave iodine enriched egg which can fulfill $44 \%$ of daily requirements of iodine for children of 1-10 years. The results of this study regarding egg iodine concentration are also in concurrent with the findings of Rottger et al. [19] who recorded linear correlation between iodine content in feed and egg yolk.

In this study, the reduction in the iodine content of eggs after boiling ranged between $10 \%$ and $15 \%$. In concurrent to this lower iodine recovery in the case of egg boiled for $30 \mathrm{~min}$ was also reported by Lipiec et al. [20]. While, Songserm et al. [13] studied iodine stabilization of iodine-enriched eggs before boiling followed by two methods of boiling, i.e. short time (soft boiled egg) and long time (hardboiled egg) and reported no any significant $(\mathrm{p}>0.05)$ difference in the iodine levels of boiled and unboiled eggs.

Among iodine supplemented diets, minimum and significantly $(\mathrm{p}<0.05)$ lowest feeding cost (Rs per dozen or per kg egg mass) was noticed in layers receiving $6.50 \mathrm{mg} / \mathrm{kg}$ iodine in their diet. Further, the inclusion of higher levels of iodine significantly $(\mathrm{p}<0.05)$ increased the feeding cost in layers. In support to our results, Malak et al. [18] also reported improved economic efficiency of laying hens fed 0.6, 1.2, 2.4 and $4.8 \mathrm{ppm}$ iodine in their diet as compared to control.

\section{Conclusion}

From the results of the present experiment, it was concluded that iodine at $6.50 \mathrm{ppm}$ in layers diet was economically better for the production of iodine enriched eggs followed by feed iodine supplementation at $3.25 \mathrm{ppm}$ as compared to control and other treatment groups.

\section{Authors' Contributions}

SN and RPSB have designed the plan of work. SS carried out the laboratory work and analyzed the results. AN and CDM drafted and RK revised the manuscript. All the authors read and approved the final manuscript.

\section{Acknowledgments}

The authors are thankful to The Dean, Collage of Veterinary Science and Animal Husbandry, Jabalpur for providing support and necessary laboratory facilities to carry out this research.

\section{Competing Interests}

The authors declare that they have no competing interests.

\section{References}

1. Al-Massad, M., Al-Shdefat, R. and Khashroum, A. (2011) The effects of microbial phytase and dietary calcium level on the performance and eggshell quality in laying hens fed marginal phosphorus diets. Asian J. Anim. Sci., 5: 118-126.

2. ACC/SCN. (2004) Fifth Report on the World Nutrition Situation: Nutrition for Improved Development Outcomes. ACC/SCN, Geneva.

3. Krzepiłko, A., Zych-Wężyk, I. and Molas, J. (2015) Alternative ways of enriching the human diet with iodine. $J$. Pre-Clin. Clin. Res., 9(2): 167-171.

4. Nimalaratne, C. and Wu, J. (2015) Hen egg as an antioxidant food commodity: A review. Nutrients, 7: 8274-8293.

5. McDowell, L.R. (1992) Minerals in Animal and Human Nutrition. Academic Press Inc., Harcourt Brace Jovanovich, USA. p524.

6. NRC. (1994) Nutrient Requirements of Poultry. $9^{\text {th }}$ ed. National Academy of Sciences, USA. p19-34.

7. Trokhimenko, O.M. and Zaitsev, V.N. (2004) Kinetic determination of iodide by the sandell-kolthoff reaction using diphenylamine-4-sulfonic acid. J. Anal. Chem., 59: 491-494. 
8. AOAC. (2000) Official Methods of Analysis. 17 $7^{\text {th }}$ ed. Association of Official Analytical Chemists, Washington, DC.

9. Snedecor, G.W. and Cochran, W.G. (2004) Statistical Methods. $9^{\text {th }}$ ed. The Iowa State University Press, Ames, Iowa, USA.

10. Kaufmann, S., Wolfram, G., Delange, F. and Rambeck, W.A. (1998) Iodine supplementation of laying hen feed: A supplementary measure to eliminate iodine deficiency in humans. Z. Ernahrungswiss, 37(3): 288-293.

11. Yang, L.I.E., Coa, S., Cheng, M., Chen, L. and Chen, K. (2004) Effects of iron, zinc, iodine and selenium levels in rations on activities of metabolic enzymes of layers and egg quality. J. Huazhong Agric. Univ. China, 51: 352-413.

12. Ramune, C., Bobiniene, R., Vytautassirvydis, D., Gudaviciute, M. and Inga, K. (2008) Effect of stable iodine preparation on the quality of poultry products. Vet. ZootechLith., 42(64): 1392-2130.

13. Songserm, O., Chewprecha, W., Sinawat, S., Chotvichien, S. and Suakam, P. (2006) Iodine supplementation in layer diets for commercial production of iodine-enriched eggs. The Proceedings of $44^{\text {th }}$ Kasetsart University Annual Conference Animals, Veterinary Medicine. p257-264.

14. Słupczynska, M., Jamroz, D., Orda, J. and Wiliczkiewicz, A. (2014) Effect of various sources and levels of iodine, as well as the kind of diet, on the performance of young laying hens, iodine accumulation in eggs, egg characteristics, and morphotic and biochemical indices in blood. Poult. Sci., 93(10): 2536-2547.

15. Saki, A.A., Farisar, M.A., Aliarabi, H., Zamani, P. and Abbasinezhad, M. (2012) Iodine enriched egg production in response to dietary iodine in laying hens. J. Agric. Technol., 8(4): $1255-1267$

16. Gjorgovska, N. and Kiril, F. (2010) Enriching table eggs with iodine. Lucrări Ştiinţifice, 53(15): 332-335.

17. Travnicek, J., Korupova, V., Herzig, I. and Kursa, J. (2006) Iodine content in consumer hen eggs. Vet. Med., 51: 93-100.

18. Malak, N.Y.A., Osman, S.M.H., Bahakaim, A.S.A., Omar, A.S. and Ramadan, N.A. (2012) Effect of using different levels of iodine in layer's diets on egg iodine enrichment. Egypt. Poult. Sci., 32: 851-864.

19. Rottger, A.S., Halle, I., Wagner, H., Breves, G., Danicke, S. and Flachowsky, G. (2012) The effects of iodine level and source on iodine carry-over in eggs and body tissues of laying hens. Arch. Anim. Nutr., 66(5): 385-401.

20. Lipiec, E., Warowicka, O., Ruzik, L., Zhou, Y., Jarosz, M. and Połec-Pawlak, K. (2012) Investigation of iodine bioavailability from chicken eggs versus iodized kitchen salt with in vitro method. Eur. Food Res. Technol., 234: 913-919.

$* * * * * * * *$ 